\title{
Contemporary problems and challenges of sustainable distribution of perishable cargoes: Case study of Polish cold port stores
}

\author{
Ludmiła Filina-Dawidowicz $^{1}$ (D) Anna Wiktorowska-Jasik ${ }^{1}$ (D)
}

Received: 8 June 2020 / Accepted: 17 June 2021 / Published online: 25 June 2021

(C) The Author(s) 2021

\begin{abstract}
Nowadays, a lot of attention is given to the issues of sustainable development of transport. Transport and logistics companies, including those involved in distribution of perishable goods, undertake different activities in order to reduce negative impact of transport on the environment. The purpose of the article is to determine the principles of sustainable distribution of perishable goods and to examine the current state and plans of its principles application in business practice on the cold port stores example. Contemporary problems of sustainable distribution of perishable cargo have been identified. Marketing research was used to identify the main directions of activities undertaken by port cold stores in the field of sustainable distribution of food perishable goods. The case study of port cold stores located in Poland was considered. According to the examined cold stores, economic and organizational factors are the most important among the factors set. The challenges faced by cold port stores in their efforts to comply with the principles of sustainable distribution were recognized. Moreover, research indicates that port cold stores are aware of their role in the sustainable distribution of perishable cargoes and strive to improve its conditions. As the result of the research, the areas of possible improvements in the functioning of cold stores have been specified. The article presents a new perspective on the problems of perishable cargo sustainable distribution as a link of supply chain.
\end{abstract}

Keywords Sustainable distribution $\cdot$ Cold store $\cdot$ Perishable cargo $\cdot$ Supply chain

Ludmiła Filina-Dawidowicz

ludmila.filina@zut.edu.pl

Anna Wiktorowska-Jasik

anna.wiktorowska-jasik@zut.edu.pl

1 Department of Logistics and Transport Economics, Faculty of Maritime Technology and Transport, West Pomeranian University of Technology, Szczecin, al. Piastów 41, 70-065 Szczecin, Poland 


\section{Introduction}

A dynamic development of perishable goods deliveries is observed worldwide. Over the past 10 years, the growth in seaborne reefer trade was 3.6\% annually (Drewry Maritime Research, 2018). According to Drewry Maritime Research report (2018) global seaborne reefer trade in 2017 reached 124 million tons, and its growth will still continue. In the opinion of Seabury Consulting analysts (Seabury Global Ocean Trade Database, 2017) growth in the amount of transported cargo will be continued in the nearest future by approximately $4 \%$ annually.

Perishable goods are first of all food, which may be transported in a frozen or chilled state, as well as other cargo (including plants and flowers, pharmaceutical products, chocolate, confectionery products and beverages etc.). These goods require special conditions for transport and storage (Filina-Dawidowicz, 2014). Specific conditions should be controlled properly due to products limited shelf life. Therefore, appropriate measures should be implemented to prevent spoilage of perishable goods within the particular links of supply chains (Hammond et al., 2015; Kaipia et al., 2013; Lipińska et al., 2019).

According to Food and Agriculture Organization of the United Nations (FAO, 2019) each year around 14 percent of food produced is lost from post-harvest up to, but not including, the retail level. Levels of loss are higher for fruits and vegetables than for cereals and pulses. A considerable share of these losses is caused by non-optimal cold chain processes and management (Jedermann et al., 2014). Therefore, good physical infrastructure and efficient trade logistics are of key importance to prevent food losses (FAO, 2019).

A dynamic development of globalization and internationalization of business operations, extension of the cooperation areas have contributed to the development of the international trade, including import and export of food products (Renko et al., 2019). Along with that, longer spatial distances are observed in the supply chain between cargo senders and recipients, resulting not only in increased inventory levels but also costs of transport and storage (Onstein et al., 2019). As an outcome, the development of goods distribution structures take place, which should ensure the required capacity of the supply chain (Lemmens et al., 2016).

In the products distribution that involves cargo carriage by sea, the port facilities play an important role (Rumaji \& Adiliya, 2019; Santos et al., 2018). These facilities integrate various modes of transport, allow temporary storage of products and provision of additional services to the client's order (Filina-Dawidowicz \& Gajewska, 2018; Wiktorowska-Jasik, 2017). Depending upon the structure of the whole supply chain, they can play the role of leading or indirect nodes in the chains, may form the transit points or be the places of the retail distribution. In case of food deliveries by reefer ships, the port cold stores are the places for proving comprehensive cargo service.

Logistic operators involved in the perishable goods distribution look for ways to increase their market position and more often pay attention to the need to observe the principles of sustainable distribution of goods (Renko et al., 2019). Sustainable approach in distribution requires compliance with certain conditions for the companies operation, which, on the one hand, should be profitable for the enterprise, and on the other, be held with the respect for the natural environment.

It should be noted that most sustainable development goals pay a lot of attention to electrical/ fuel consumption reduction (United Nations, 2021). According to Accorsi et al. (2017) as much as $15 \%$ of total worldwide energy already fuels cold chains infrastructures and since $40 \%$ of food deliveries would need refrigeration. It is expected that the growth of 
global food demand and widening of the global supply chains will enormously increase the request for energy and associated carbon emissions. However, the issue of sustainable distribution of perishable goods is more complex. Considering the fact that implementation of perishable goods distribution requires to ensure the appropriate cargo transport and storage conditions (Filina-Dawidowicz, 2014; Joshi et al., 2018), it is necessary to look for more environmentally friendly solutions, allowing simultaneous reduction in transport costs and increased safety of the cargo being transported (Benali et al., 2020; Accorsi et al., 2017; Hsiao et al., 2018).

Conducted literature review revealed that available studies widely analyze supply chains' functioning; however, the aspects of perishable goods sustainable distribution, as a significant part of these chains performed with participation of port cold stores, were investigated to the small extent. The problems and challenges faced by these stores were not analyzed in detail. Moreover, the way to conduct the analysis and criteria for the assessment of sustainable distribution of products that require proper conditions of storage and transport were not formulated.

Taking the above into consideration, the motivation of Authors of the presented article was to characterize sustainable distribution of perishable goods and identify the activities taken presently and planned in future by cold stores significant in terms of ensuring it. The scientific purpose of the article was to determine the principles of sustainable distribution for perishable goods and examine this principles application in business practice on the example of port cold stores located in Poland. The article focuses on perishable goods distribution as a link of the supply chain, performed with participation of port cold stores. This link services products sent by the manufacturers to the end recipients on the route that is performed using land and waterborne transport means. The deliveries of food loads, mostly frozen (fish, meat), have been considered.

The paper contains literature review section. Then, research methodology and accurate results are presented in consecutive sections. The paper is summed up with conclusions and discussions part that include future potential research interests.

\section{Literature review}

The issues related to the supply chains functioning are widely analyzed in the available literature. It presents approaches that describe ways/methods/opportunities for increasing sustainable management and development, including the impact of green practices on supply chain efficiency (Adobor, 2019; Azevedo et al., 2011; Carter \& Easton, 2011; Fahimnia et al., 2015). Methods and models of integrated supply chain network design were developed (Danielis et al., 2018; Lemmens et al., 2016). These models take into account i.e., the reliability, different numbers of suppliers and buyers etc. (Lin et al., 2017). A lot of attention is devoted to the issues of sustainable supply chain management (Blome et al., 2014; Yun et al., 2019) and integrated planning of flows between the links of supply chains (Brahmi et al., 2020; Liu et al., 2019; Palmieri et al., 2019; Wu et al., 2020). Sustainability marketing is promoted by Belz and Peattie (2009). Bai et al. (2012) made a research on the ecological sustainable performance measures for supply chain management. The attempts were done to define future steps and perspectives of sustainable supply chains development (Carter \& Easton, 2011). The influence of green practices on supply chain performance in the context of the automotive industry was considered by Azevedo (2011). It should be 
mentioned that these positions are related to whole supply chain and do not provide the complex view on sustainable distribution of perishable goods.

Available studies examine only selected problems dealing with perishable goods sustainable supply chains and related distribution processes. Renko et al. (2019) paid attention that the food supply chains tend to be long, global and highly interconnected, it leads to greater risk exposure, requires temperature monitoring at every link in the supply chain. Rohmer et al. (2019) analyzed the sustainability indicators and conflicting nature of different sustainability aspects in food systems. Aung and Chang (2014) analyzed safety and traceability in food supply chains. Interval model applied to consider multi stage distribution systems of perishable goods was examined by Akhmad et al. (2019). The available approaches make it possible to support decision-making processes for shaping the perishable goods supply chains (Garnier et al., 2019; Chaudhuri et al., 2018).

Sonnino et al. (2014) discussed inextricably linked barriers to 'sustainable food security' paying attention to economic, social and ecological effects of global environmental change at different stages of the food system. The study highlighted a series of cross-cutting issues and pointed a need for a renovated focus on the different nodal points of the food system. Different viewpoints on food system change were examined by Haysom et al. (2019). It was also noted that it is possible to recover part of the food during the loading, transportation and unloading stages (Lipińska et al., 2019).

During distribution of perishable goods the number of problems may occur. These problems may deal with cargo delays, food losses (Kashyap \& Agarwal, 2020) and packaging waste, as well as food quality degradation that causes costs (Rong et al., 2011), etc. Quality prediction solutions in distribusion process were proposed by Meng et al. (2018). Accorsi et al. (2017) in their paper incorporated the interactions of distribution constraints and climate conditions for planning of processing and distribution operations in cold chains.

Sustainable distribution may cover different aspects. Hsiao et al. (2018) in their research investigated a distribution plan including required fleet size, vehicle routing sequence accounting for the quality degradation during delivery. The study results indicated that the fulfillment of various requirements of different customers for various fruits and vegetables and quality levels can be ensured with cost considerations.

The number of publications paid attention to importance of information exchange during the cargo delivery. Jedermann et al. (2014) promoted intelligent food logistics, focusing on technical solutions, such as the wireless sensor and communication system for remote quality supervision. Kaipia et al. (2013) examined material and information flow issues, specifically sharing demand and shelf-life data. It was stated that the performance of the perishable food chain can be improved by more efficient information sharing, as well as changes in the supply chain structure are needed to speed up the deliveries and ensure shelf availability.

The issue of energy consumption and related costs was also examined in the literature (Varjan et al., 2019; Wang et al., 2020). Hammond et al. (2015) noticed challenges for feeding a growing and increasingly urbanized global population as finite supplies of fossil fuels rapidly deplete. Gallo et al. (2017) proposed a mixed integer linear programming model to minimize the total energy consumption associated with the cold operations experienced by perishable products. New Silk Road connecting Europe and China was considered and alternative routes were analyzed.

Ecological solutions in logistics processes performance were considered by Bai et al. (2012) and Lattila et al. (2013). Moreover, Wang et al. (2020) highlighted that cold chain logistics companies have to pay attention to customer satisfaction and carbon emission for better development. Foltin et al. (2015) stated that properly executed evaluation of 
companies enables customers to take right decisions on contracting services and stimulate the development of those companies. It should be noted that the most number of studied publications is concentrated on the efficiency of distribution processes, but do not describe the way to assess the efficiency of sustainable distribution of perishable goods.

There are research results describing infrastructure influence on the efficiency of cargo distribution. Rumaji and Adiliya (2019) used scenarios analysis to find the best solutions to improve the Tenau-Kupang port connectivity in Indonesia and recommended re-configure port infrastructure to become transshipment port in order to better attract the cargo volume. Semenov et al. (2019) paid attention to road infrastructure influence on distribution of sensitive cargo and developed procedures that may allow to choose a transport route considering appearance of so-called high-risk zones within road infrastructure. Khomnamool (2001) noted that cold stores have to be equipped with specialized devices and technologies that allow the necessary cargo transport conditions to be maintained. Available literature does not present current problems and challenges of port cold stores to ensure sustainable distribution of perishable goods. Moreover, available positions do not investigate the port cold stores representatives attitude to the issues of goods sustainable distribution.

Sustainable distribution of goods is influenced by different factors, including technical and technological (Leleń \& Wasiak, 2019), ecological/environmental (Abrutytu et al., 2014; Accorsi et al., 2017; Garnier et al., 2019), economic/financial (Benali \& Feki, 2020; Brahmi et al., 2020), human factor (Filina-Dawidowicz, 2014; Santos et al., 2018), organizational (Kush et al., 2019) and other. It should be noted that appropriate policy rules and regulations should be developed to increase food safety and eliminate food losses and waste (FAO, 2019; Sonnino et al., 2014). However, mentioned positions do not present comprehensive view on the factors influencing the sustainable distribution implemented by port cold stores.

The conducted literature analysis argues for the need to fill the gap in research on the sustainable distribution of perishable goods provided by port cold stores. Therefore, the activities of cold stores as well as problems and challenges of these facilities in efforts to fulfill the principles of sustainable distribution should be investigated in more details.

\section{Research methodology}

For the purpose of the study, the authors introduce the term "sustainable distribution of perishable goods." It will be understood as the process of the whole delivery of goods, starting from storage, through orders, their collection and processing, packaging and other activities to physical delivery of the goods to the client. According to the concept of sustainable distribution, particular processes of products delivery to recipients should ensure the most beneficial solutions, both in terms of environmental protection and the business's economic objectives.

Based on the analyzed theoretical background, the following research hypothesis have been formulated: Port cold stores as highly energy-intensive facilities are aware of their role in sustainable distribution of perishable goods and strive to improve the conditions of this distribution.

The research problem undertaken in this article covers, in particular, the investigation of:

- The role of port cold stores in sustainable distribution of perishable goods, 
- Environmentally friendly behaviors of port cold stores,

- Conditions necessary to ensure sustainable distribution,

- The principles of sustainable distribution of perishable goods,

- Present problems and challenges for cold stores in efforts to fulfill this principles.

The analysis of the application of sustainable distribution principles in business practice on the example of port cold stores has been conducted using questionnaire techniques and marketing interviews methods. The research methodology has been presented in Fig. 1.

After carrying out the literature analysis, the concept of sustainable distribution was defined and conditions and factors that pose the greatest problems in ensuring its principles were identified. The draft of concept was discussed with employees of port cold stores in Poland involved in the distribution of perishable goods (4 persons). They were mainly managers (heads of the departments of warehousing, customer service, quality management). These were in-depth interviews based on a prior investigation of the research problem. In a result of conversations, the final concept was elaborated and the factors which currently create the greatest problems for port cold stores to ensure the principles of sustainable distribution have been identified. These include the following groups of factors:

- Economic (including financial and human resources factors),

- Technical and technological,

- Legal (legislative), including administrative factors,

- Organizational.

The group of economic factors determine general conditions of cold store's business operations. The factors that were qualified to this group included among others financial and human resources (HR) factors. These factors are related to the general macroeconomic situation of the country, including the pace of growth in the economy. It was revealed that the level of foreign trade and demand growth, as well as the labor market, is significantly important for cold stores, in particular the access to qualified and experienced human resources. It is necessary to emphasize that cold stores are very sensitive

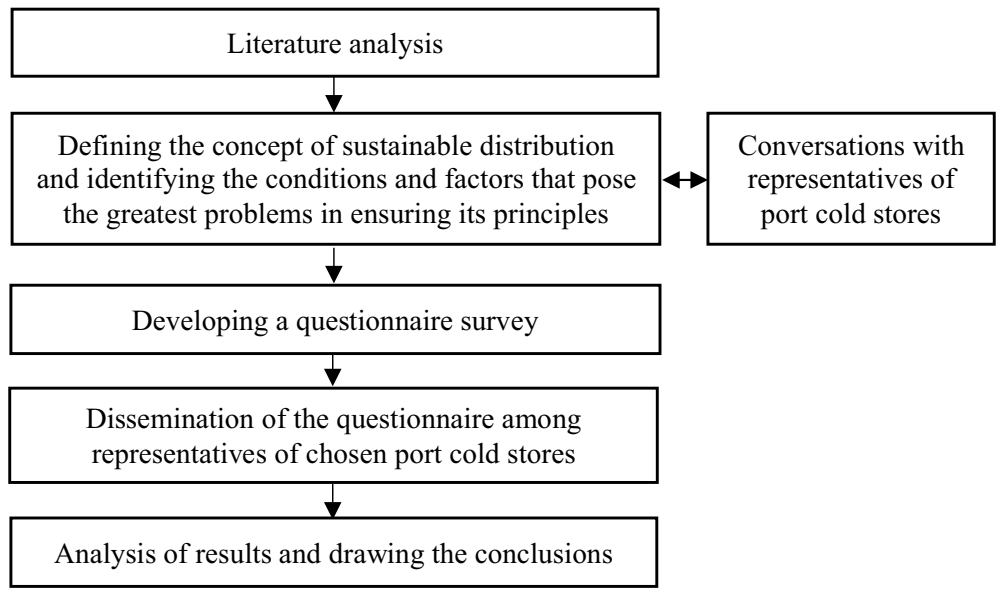

Fig. 1 Research methodology. Source: own elaboration 
to business cycles, as well as prices of logistic services and energy. In addition, cold stores have no impact on economic factors, as they result from the external environment. Nevertheless, they should analyze them systematically, in order to obtain complex information that can fundamentally affect their justified actions.

Factors included in the group of technical and technological factors are related to the general technological level of a cold store. It is determined by the degree of modernity of the cold store, which is influenced i.e., by the type of applied technology and the materials used for its construction. They affect the level of thermal tightness and thermal insulating power of the facility. Account has also been taken of: used means of internal transport, cold store's infrastructure and equipment elements, cold store's storage and transshipment devices. In addition, this group of factors also includes: any devices improving the quality of cold store operation, affecting its effectiveness, observance of quality standards and processes environmental friendliness etc.

Legal (legislative) factors have been defined as the group of legal regulations and standards that govern the cold store operation. These include: tax, customs regulations, regulations concerning business operations in port areas, labor law, directives and environmental protection regulations etc. The group of legal (legislative) factors also includes administrative factors, and in particular the degree of state institutions' interference with the work of a cold store etc.

The group of organizational factors is related to the business' organizational structure. Factors in this group include: adopted management rules and styles, principles of cooperation with cargo suppliers and recipients, ways of completing particular processes, as well as the adopted action objectives and business development strategy etc.

Based on literature review results, as well as information received by representatives of cold port stores the questionnaire was developed. The questionnaire contained 6 questions (Table 1). There were closed questions, part of them was assessed by respondents using Likert scale (from 1 to 5). The survey was to examine the role of port cold stores in food perishable cargo sustainable distribution and activities taken for that purpose. The case study of cold stores located in Polish seaports was considered.

After receiving completed questionnaires, the obtained data was analyzed in detail and conclusions were drawn.

Table 1 List of questions in the questionnaire survey. Source: own elaboration

\begin{tabular}{ll}
\hline No & Question \\
\hline 1 & What is the role of cold stores in sustainable distribution of perishable goods? \\
2 & What is the degree of port cold stores' compliance with the principles of sustainable distribution? \\
3 & What conditions are applied in order to fulfill the principles of sustainable distribution in cold stores? \\
4 & What factors create the greatest problems in meeting these principles? \\
5 & What are the challenges for cold stores to ensure sustainable distribution of perishable goods? \\
6 & What are the consequences of failure to fulfill the principles of sustainable distribution? \\
\hline
\end{tabular}




\section{Results}

\subsection{Case study description}

The survey was conducted in port cold stores located in Polish seaports. The analyzed facilities are the cold stores operating within the ports of Szczecin (cold stores A and B), Gdańsk (cold store C), Gdynia (cold store D). The uppercase are used to determine the cold stores, their names are not disclosed. A brief description of the selected cold stores is presented in Table 2 .

This selection resulted from the assumption that analysis would include these cold store facilities that are located in ports of strategic importance for the Polish economy. The choice of these cold stores was mostly determined by their location (all stores are situated in port areas) making them operating in similar conditions of the market environment. In addition, they are nodes of international transport corridors within the Trans-European Network for Transport (TEN-T).

The cold stores being examined are characterized by a broad scope of services. Two of them offer complex warehousing services and are equipped with devices ensuring full traceability of logistic processes related to cargo flow (cold stores A and C). Two other cold stores also use cargo identification systems (limited to basic warehouse management systems), but their scope of services is not so complex. All the analyzed cold stores are characterized by a high warehouse capacity. One of them has more than 30,000 pallet holding positions, as well as over 6500 positions for cargo storage in bulk. Other three facilities have warehouse areas exceeding 10,000 pallet holding positions, free space for storage of frozen cargo in bulk. Cold store D in addition to frozen cargo handles chilled loads. A common feature, resulting from the location of the studied cold stores, is a possibility to handle cargo directly from sea vessels, that gives them additional competitive advantage.

The survey was sent to port cold stores representatives in the electronic form. Study was conducted in January and February 2019. The questionnaires were filled in by 16 employee, mainly by management staff having many years of professional experience and directly involved in cold stores' distribution processes.

\subsection{Survey analysis}

Considering the conditions for port cold store operations, it was possible to obtain an answer to the question about the role of particular cold stores in sustainable distribution of perishable goods. Respondents put their assessments using Likert scale, where 1-of smallest, and 5-of greatest importance. The obtained answers indicate that 3 cold stores define their role as leading ( 5 points out of 5), and 1 of them as significant (4 points out of 5 ). This means that these cold stores play an important role in goods distribution process within the whole supply chain. It can therefore be concluded that they affect the other participants of the supply chain, for example, by imposing specific service standards or the need to operate environmentally friendly systems etc. On the other hand, answers to the next question about the degree of compliance with the principles of sustainable distribution by each cold store were slightly different: 2 cold stores confirmed that they observed these principles on a very high level, 1 cold store to a significant degree and 1 to a medium degree (Fig. 2). It can therefore be concluded that cold stores see the need for further development in order to improve the application of the principles of sustainable distribution. 


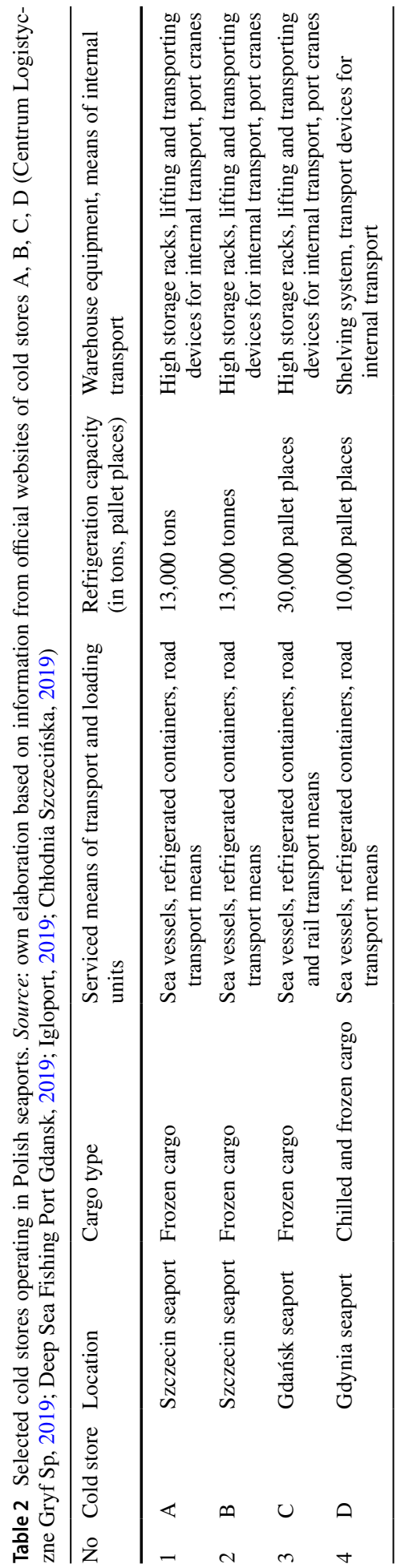




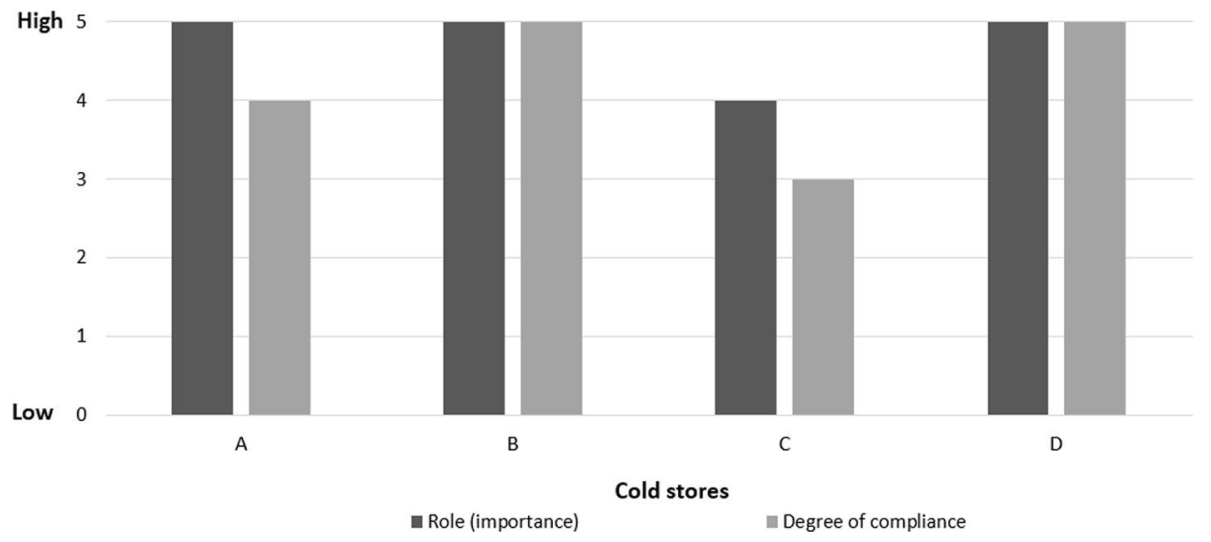

Fig. 2 Role (importance) of cold stores in sustainable distribution of perishable goods and degree of cold store's compliance with the principles of sustainable distribution (rating given by cold store). Source: own elaboration

The subsequent part of research referred to the conditions being met by particular cold stores in order to observe the principles of sustainable distribution. It allowed to investigate the activities currently undertaken and planned to be implemented in future (Fig. 3). The results obtained expressly indicate that, for all the examined cold stores, three conditions are priority in observing the principles of sustainable distribution, these include: rational waste management, provision of services based on sustainable resource management, and electronic data exchange. An important requirement is also possession of certificates and application of energy-efficient and low-emission solutions, as well as application of environmentally friendly storage systems. In should be noted that port cold stores had the

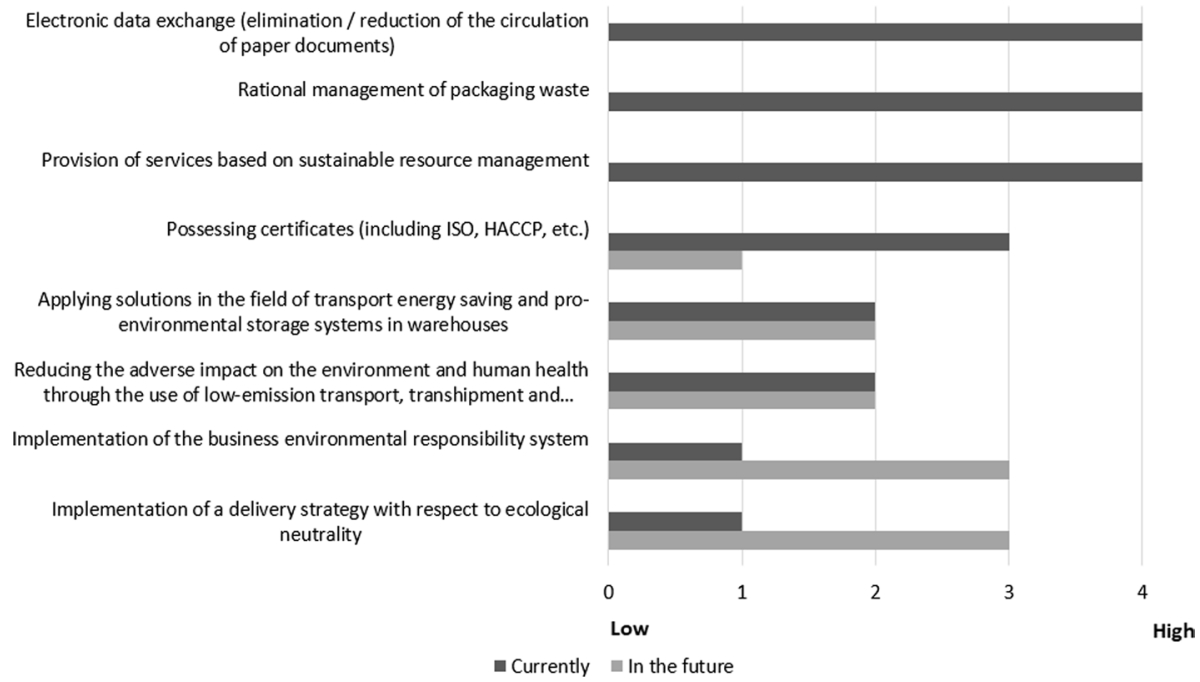

Fig. 3 Conditions for sustainable distribution, presently met and assumed in future (number of cold stores indicating the option). Source: own elaboration 


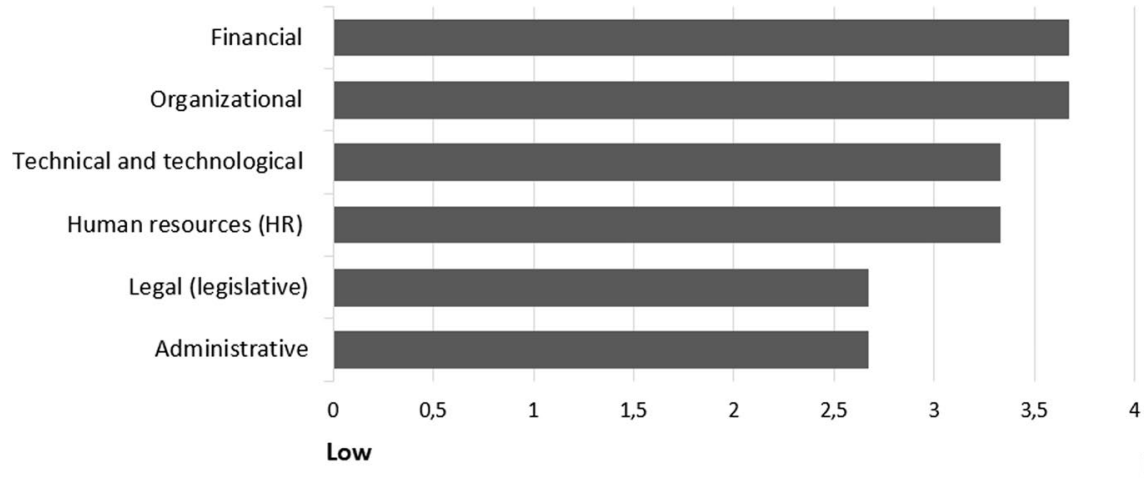

Fig. 4 Factors creating the greatest problems in observing the principles of sustainable distribution (average mean). Source: own elaboration

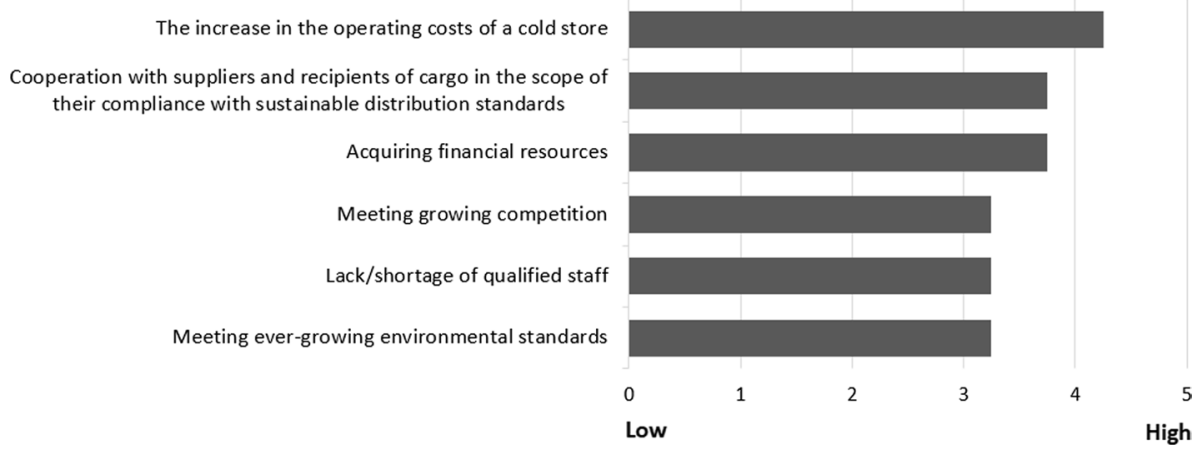

Fig. 5 Market factors that pose challenges in ensuring sustainable distribution of perishable cargo (average mean). Source: own elaboration

opportunity to evaluate 'electronic data exchange' criterion comprehensively, paying attention to payments, scheduling and planning, as well as other aspects of data transmission, including the quality of the provided data about the product. Conditions that cold stores want to meet in future include: observing the assumptions of the business environmental responsibility system and implementing delivery strategies with preserved environmental neutrality.

Further, the factors that create the greatest problems for particular cold stores in fulfilling the principles of sustainable distribution have been revealed (Fig. 4). The assessment in the study was score-based, and the answers were given in the scale from 1 to 5 , where 1 - of smallest, and 5-of greatest importance. Among the answers obtained, financial and organizational factors were indicated as more important. Substantial difficulties are also caused by technical and technological and HR factors. The distribution of these answers can imply that cold stores come across the greatest problems in obtaining funds and optimal organization of the processes. This can result from difficulties in obtaining experienced and qualified staff, which the cold stores emphasized in the study.

The cold stores representatives similarly ranked market factors, which pose challenges for them in ensuring sustainable distribution (Fig. 5). Increasing operating costs of a cold 
store, problems in cooperation with suppliers and recipients regarding their fulfillment of the principles of sustainable distribution, as well as acquiring financial resources, were indicated as more important factors.

The consequences for cold stores, resulting from non-fulfillment of the principles of sustainable distribution and their effect on the effectiveness of the entire supply chain of perishable goods, were also determined (Fig. 6). The obtained results confirm a significant effect of non-fulfillment of these principles on the effectiveness of the supply chain, and in particular on the economic effectiveness of delivery processes and cold store's profits. Delays in deliveries that generate financial losses were indicated as the most important consequence. These delays can result from problems related to the organization of delivery processes, what is also emphasized by the research findings presented in Fig. 4. However, suppliers not meeting environmental standards are subjected to additional checks, which may prolong the cargo handling time.

\section{Conclusions and discussions}

This article presents a new view on the problem of sustainable distribution of perishable goods. The term "sustainable distribution of perishable goods" has been explained in the paper, as well as conditions that should be met by cold stores in order to preserve it have been recognized.

The case study of cold port stores located in Poland was analyzed and the opinions of 4 port cold stores representatives have been examined using the marketing research method. The factors that create the greatest problems in pursuit of fulfilling the principles of sustainable distribution have been identified and assessed. The obtained research results indicate that financial and organizational factors create the greatest problems in cold store's operations. Challenges have also been specified for cold stores in pursuit of fulfilling the mentioned principles. It should be highlighted that cold stores have emphasized growing operating costs as the greatest challenge. It is related to possible growth in electric energy prices in the country, which will additionally motivate cold stores to take intensive actions to be more energy efficient. The consequences resulting from failure to meet the principles of sustainable distribution have been indicated.

The obtained distributions of answers are the foundation for assessing the level of advancement in analyzed port cold stores' actions in sustainable distribution processes.

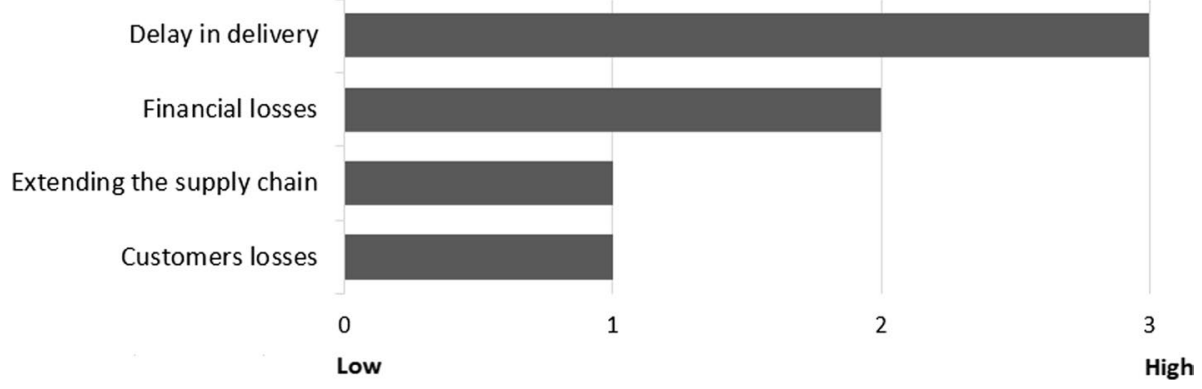

Fig. 6 Consequences of non-fulfillment of the principles of sustainable distribution having effect on the effectiveness of the supply chain (number of cold stores indicating the option). Source: own elaboration 
They have also given a certain picture of the impact of these facilities' operations on the effectiveness of distribution process and whole supply chain. This effect has been determined as very significant, which has been confirmed by the received results. Each of the analyzed cold stores stated that it plays a very important role, by imposing/shaping the terms of cooperation with its suppliers and recipients.

The level of difficulty and degree of involvement of particular cold stores in environmentally friendly operations had been assessed. The results have indicated that each of the analyzed cold stores focuses its operations on sustainable distribution, though believes that fulfillment of all its principles is relatively difficult.

The obtained research findings have made it possible to confirm the research hypothesis. Port cold stores are aware of their role in sustainable distribution of perishable goods. They notice the need to consider its requirements in distribution processes. In addition, they see the necessity for continuous improvement in their efforts in this respect. Based on the results of the research, the port cold stores obtained systemized knowledge about the areas in which they should undertake wider activities aimed at the sustainable distribution of perishable cargoes.

It should be noted that the presented research results are based on the case study analysis and consider the small number of entities located in seaports involved in distribution of perishable goods. The obtained test sample is limited, however, representative, and may influence the obtained research results. Nevertheless, the results indicate trends in the proecological behavior of port cold stores in the area of perishable cargoes distribution. Moreover, it was not possible to compare the research results to other works, because the similar research results are unavailable.

Although the research covered a specific geographical area (Poland), the results may be interesting for other regions. The operations performed in the cold stores are generally standardized within the international supply chains, but there may be differences in the range of services and cargo handling procedures applied. The type of serviced products (frozen or chilled), as well as environmental conditions of the region, also influences cold stores operation. The difference between the product storage temperature and the ambient temperature will determine the energy consumption necessary to ensure products storage conditions. In some regions (e.g., Central Europe), the range of temperature fluctuation during the year may vary from $-10{ }^{\circ} \mathrm{C}$ in winter up to $+30{ }^{\circ} \mathrm{C}$ in summer. Such conditions may affect the scope of investments needed. Nevertheless, the principles of sustainable distribution studied by the authors are the same for all facilities, regardless of geographic location and environmental conditions. However, cold stores location may affect the differences in their representatives assessments of individual factors importance that may influence factors ranking. Therefore, the authors would like to continue research and investigate the opinions of managers employed in cold stores located in other geographical areas in future studies. This will allow for a detailed statistical analysis of the results.

In order to fully examine the importance of cold stores in goods sustainable distribution, it is justified to conduct further research among entities operating in different market conditions (e.g., land cold stores) located in Poland and other countries. Comparison of the results received from land cold stores and those located in seaports will allow to receive more reliable view on the problem of observing the principles of perishable goods sustainable distribution. These problems, as well as perishable goods spoilage index assessment in relation to sustainable distribution performed by cold port stores, will also constitute the direction of our further research. The research findings could be interesting for supply chain management decision makers. 
Funding West Pomeranian University of Technology, Szczecin.

Data availability The data presented in the article are transparent.

\section{Declaration}

Conflict of interest The authors declare that they have no conflict of interests.

Open Access This article is licensed under a Creative Commons Attribution 4.0 International License, which permits use, sharing, adaptation, distribution and reproduction in any medium or format, as long as you give appropriate credit to the original author(s) and the source, provide a link to the Creative Commons licence, and indicate if changes were made. The images or other third party material in this article are included in the article's Creative Commons licence, unless indicated otherwise in a credit line to the material. If material is not included in the article's Creative Commons licence and your intended use is not permitted by statutory regulation or exceeds the permitted use, you will need to obtain permission directly from the copyright holder. To view a copy of this licence, visit http://creativecommons.org/licenses/by/4.0/.

\section{References}

Abrutyte, E., Žukauskaite, A., Mickevičiene, R., Zabukas, V., \& Paulauskiene, T. (2014). Evaluation of NOx emission and dispersion from marine ships in Klaipeda sea port. Journal of Environmental Engineering and Landscape Management, 22(4), 264-273. https://doi.org/10.3846/16486897.2014. 892009

Accorsi, R., Gallo, A., \& Manzini, R. (2017). A climate driven decision-support model for the distribution of perishable products. Journal of Cleaner Production, 165, 917-929. https://doi.org/10.1016/j.jclep ro.2017.07.170

Adobor, H. (2019). Supply chain resilience: A multi-level framework. International Journal of Logistics Research and Applications, 22(6), 533-556. https://doi.org/10.1080/13675567.2018.1551483

Akhmad, S., Miswanto, \& Suprajitno, H. (2019). Interval model of food supply chain network at the multi stage distribution systems. International Journal of Geomate, 16(55), 125-130. https://doi.org/10. 21660/2019.55.30330

Aung, M. M., \& Chang, Y. S. (2014). Traceability in a food supply chain: Safety and quality perspectives. Food Control, 39, 172-184. https://doi.org/10.1016/j.foodcont.2013.11.007

Azevedo, S. G., Carvalho, H., \& Cruz Machado, V. (2011). The influence of green practices on supply chain performance: A case study approach. Transportation Research Part E-Logistics and Transportation Review, 47(6), 850-871. https://doi.org/10.1016/j.tre.2011.05.017

Bai, C., Sarkis, J., Wie, X., \& Koh, L. (2012). Evaluating ecological sustainable performance measures for supply chain management. Supply Chain Management-an International Journal, 17(1), 78-92.

Belz, F. M., \& Peattie, K. (2009). Sustainability marketing. A Global Perspective. Journal of Consumer Policy, 33(4), 426.

Benali, N., \& Feki, R. (2020). Evaluation of the relationship between freight transport, energy consumption, economic growth and greenhouse gas emissions: The VECM approach. Environment, Development and Sustainability, 22, 1039-1049. https://doi.org/10.1007/s10668-018-0232-x

Blome, C., Paulraj, A., \& Schuetz, K. (2014). Supply chain collaboration and sustainability: A profile deviation analysis. International Journal of Operations \& Production Management, 34(5), 639-663. https:// doi.org/10.1108/IJOMP-11-2012-0515

Brahmi, A., Hadj-Alouane, A. B., \& Sboui, S. (2020). Dynamic and reactive optimization of physical and financial flows in the supply chain. International Journal of Industrial Engineering Computations, 11(1), 83-106. https://doi.org/10.5267/j.ijiec.2019.6.003

Carter, C. R., \& Easton, P. L. (2011). Sustainable supply chain management: Evolution and future directions. International Journal of Physical Distribution \& Logistics Management, 41(10), 46-62.

Centrum Logistyczne Gryf Sp. z o.o. (2019). http://chlodniagryf.pl/—official website of cold port store. accessed: 01.09.2019.

Chaudhuri, A., Dukovska-Popovska, I., Subramanian, N., Chan, H., \& Bai, R. (2018). Decision-making in cold chain logistics using data analytics: A literature review. International Journal of Logistics Management, 29(3), 839-861. https://doi.org/10.1108/IJLM-08-2018-340 
Chłodnia Szczecińska. (2019). http://www.chlodniaszczecinska.pl/—official website of cold port store. accessed: 01.09.2019.

Danielis, R., Rotaris, L., \& Monte, A. (2018). Composite indicators of sustainable urban mobility: Estimating the rankings frequency distribution combining multiple methodologies. International Journal of Sustainable Transportation, 12(5), 380-395. https://doi.org/10.1080/15568318.2017.1377789

Deep Sea Fishing Port Gdansk. (2019). http://coldstoregda.pl/—official website of cold port store. accessed: 01.09.2019.

Drewry Maritime Research. (2018). Reefer shipping annual review and forecast 2018/19. Drewry Publishing.

Fahimnia, B., Sarkis, J., \& Eshragh, A. (2015). A tradeoff model for green supply chain planning: A leanness-versus-greenness analysis. Omega-International Journal of Management Science, 54, 173-190. https://doi.org/10.1016/j.omega.2015.01.014

FAO_Food and Agriculture Organization of the United Nations. (2019). The state of food and agriculture. Moving forward on food loss and waste reduction, available online: http://www.fao.org/3/ ca6030en/ca6030en.pdf, accessed: 08.04.2021.

Filina-Dawidowicz, L. (2014). Rationalization of servicing reefer containers in sea port area with taking into account risk influence. Polish Maritime Research, 21(2), 76-85. https://doi.org/10.2478/ pomr-2014-0022

Filina-Dawidowicz, L., \& Gajewska, T. (2018). Examination of importance and range of comprehensive service for refrigerated containers in seaports. International Journal of Applied Management Science, 10(1), 26-43. https://doi.org/10.1504/IJAMS.2018.089945

Foltin, P., Gontarczyk, M., Swiderski, A., \& Zelkowski, J. (2015). Evaluation model of the companies operating within logistic network. Archives of Transport, 36(4), 21-33. https://doi.org/10.5604/ 08669546.1185196

Gallo, A., Accorsi, R., Baruffaldi, G., \& Manzini, D. R. (2017). Designing sustainable cold chains for long-range food distribution: Energy-effective corridors on the Silk Road Belt. Sustainability, 9(2044), 10. https://doi.org/10.3390/su9112044

Garnier, J., Le Noe, J., Marescaux, A., Sanz-Cobena, A., Lassaletta, L., Silvestre, M., Thieu, V., \& Billen, G. (2019). Long-term changes in greenhouse gas emissions from French agriculture and livestock (1852-2014): From traditional agriculture to conventional intensive systems. Science of the Total Environment, 660, 1486-1501. https://doi.org/10.1016/j.scitotenv.2019.01.048

Hammond, S. T., Brown, J. H., Burger, J. R., Flanagan, T. P., Fristoe, T. S., Mercado-Silva, N., Nekola, J. C., \& Okie, J. G. (2015). Food spoilage, storage, and transport: Implications for a sustainable future. BioScience, 65(8), 758-768. https://doi.org/10.1093/biosci/biv081

Haysom, G., Olsson, E. G. A., Dymitrow, M., Opiyo, P., Taylor Buck, N., Oloko, M., Spring, C., Fermskog, K., Ingelhag, K., Kotze, S., \& Agong, S. G. (2019). Food systems sustainability: An examination of different viewpoints on food system change. Sustainability, 11, 3337. https://doi. org/10.3390/su11123337

Hsiao, Y. H., Chen, M. C., Lu, K. Y., \& Chin, C. L. (2018). Last-mile distribution planning for fruit-andvegetable cold chains. International Journal of Logistics Management, 29(3), 862-886.

Igloport. (2019). http://igloport.pl/—official website of cold port store. accessed: 01.09.2019.

Jedermann, R., Nicometo, M., Uysal, I., \& Lang, W. (2014). Reducing food losses by intelligent food logistics. Philosophical Transactions A Mathematical, Physical and Engineering Sciences, 372(2017), 20130302. https://doi.org/10.1098/rsta.2013.0302

Joshi, K., Warby, J., Valverde, J., Tiwari, B., Cullen, P. J., \& Frias, J. M. (2018). Impact of cold chain and product variability on quality attributes of modified atmosphere packed mushrooms (Agaricus bisporus) throughout distribution. Journal of Food Engineering, 232, 44-55. https://doi.org/10. 1016/j.jfoodeng.2018.03.019

Kaipia, R., Dukovska-Popovska, I., \& Loikkanen, L. (2013). Creating sustainable fresh food supply chains through waste reduction. International Journal of Physical Distribution \& Logistics Management, 43(3), 262-276. https://doi.org/10.1108/IJPDLM-11-2011-0200

Kashyap, D., \& Agarwal, T. (2020). Food loss in India: Water footprint, land footprint and GHG emissions. Environment, Development and Sustainability, 22, 2905-2918. https://doi.org/10.1007/ s10668-019-00325-4

Khomnamool, N. (2001). Logistics for improvement of fish transport efficiency to consumers in Thailand. Proceedings of the Eastern Asia Society for Transportation Studies, 3(2), 543-558.

Kush, Y., Tonkoshkur, M., Ryabev, A., Galkin, A. (2019). The efficiency of goods distribution in the service sector. In Proceedings of the 33rd international business information management association conference, IBIMA 2019: education excellence and innovation management through vision 2020, (pp. 6739-6750). 
Lattila, L., Henttu, V., \& Hilmola, O. P. (2013). Hinterland operations of sea ports do matter: Dry port usage effects on transportation costs and $\mathrm{CO}_{2}$ emissions. Transportation Research Part E-Logistics and Transportation Review, 55, 23-42. https://doi.org/10.1016/j.tre.2013.03.007

Leleń, P., \& Wasiak, M. (2019). The model of selecting multimodal technologies for the transport of perishable products. Archives of Transport, 50(2), 17-33. https://doi.org/10.5604/01.3001.0013.5573

Lemmens, S., Decouttere, C., Vandaele, N., \& Bernuzzi, M. (2016). A review of integrated supply chain network design models: Key issues for vaccine supply chains. Chemical Engineering Research \& Design, 109, 366-384. https://doi.org/10.1016/j.cherd.2016.02.015

Lin, Y. K., Yeh, C. T., \& Huang, C. F. (2017). Reliability assessment of a multistate freight network for perishable merchandise with multiple suppliers and buyers. International Journal of Systems Science, 48(1), 74-83. https://doi.org/10.1080/00207721.2016.1157222

Lipińska, M., Tomaszewska, M., \& Kołożyn-Krajewska, D. (2019). Identifying factors associated with food losses during transportation: Potentials for social purposes. Sustainability, 11, 2046. https://doi.org/10. 3390/su11072046

Liu, M., Xu, X., \& Zhang, D. (2019). Integrated optimization model for distribution network design: A case study of the clothing industry. International Transactions in Operational Research, 26(4), 1269-1292. https://doi.org/10.1111/itor.12621

Meng, J. J., Qian, J., Jung, S. W., \& Lee, S. J. (2018). Practicability of TTI application to yogurt quality prediction in plausible scenarios of a distribution system with temperature variations. Food Science and Biotechnology, 27(5), 1333-1342. https://doi.org/10.1007/s10068-018-0371-8

Onstein, A. T. C., Tavasszy, L. A., \& van Damme, D. A. (2019). Factors determining distribution structure decisions in logistics: A literature review and research agenda. Transport Reviews, 39(2), 243-260. https://doi.org/10.1080/01441647.2018.1459929

Palmieri, A., Parola, F., Song, D. W., \& Baglieri, E. (2019). Integrating firms in a complex network: Evidence from maritime logistics. International Journal of Logistics Research and Applications, 22(1), 64-77. https://doi.org/10.1080/13675567.2018.1474860

Renko, S., Petljak, K., \& Naletina, D. (2019). Food integrity throughout the chain: The case of good distribution practice. Logforum, 15(1), 53-69. https://doi.org/10.17270/J.LOG.2019.318

Rohmer, S. U. K., Gerdessen, J. C., \& Claassen, G. D. H. (2019). Sustainable supply chain design in the food system with dietary considerations: A multi-objective analysis. European Journal of Operational Research, 273(3), 1149-1164. https://doi.org/10.1016/j.ejor.2018.09.006

Rong, A., Akkerman, R., \& Grunow, M. (2011). An optimization approach for managing fresh food quality throughout the supply chain. International Journal of Production Economics, 131, 421-429.

Rumaji, \& Adiliya, A. (2019). Port maritime connectivity in South-East Indonesia: A new strategic positioning for transhipment port of Tenau Kupang. Asian Journal of Shipping and Logistics, 35(4), 172180. https://doi.org/10.1016/j.ajsl.2019.12.004

Santos, A. M. P., Salvador, R., \& Guedes Soares, C. (2018). A dynamic view of the socioeconomic significance of ports. Maritime Economics \& Logistics, 20(2), 169-189. https://doi.org/10.1057/ s41278-017-0081-9

Seabury Global Ocean Trade Database. (2017). Seabury analysis, February 2017.

Semenov, I., Filina-Dawidowicz, L., \& Trojanowski, P. (2019). Integrated approach to information analysis for planning the transport of sensitive cargo. Archives of Transport, 51(3), 65-76. https://doi.org/10. 5604/01.3001.0013.6163

Sonnino, R., Faus, A. M., \& Maggio, A. (2014). Sustainable food security: An emerging research and policy agenda. International Journal of Sociology of Agriculture \& Food, 21(1), 173-188.

United Nations. (2021). https://sdgs.un.org/goals, accessed: 08.04.2021.

Varjan, P., Gnap, J., Durana, P., \& Kostrzewski, M. (2019). Research on the relationship between transport performance in road freight transport and revenues from excise duty on diesel fuel in selected European countries. Transportation Research Procedia, 40, 1216-1223. https://doi.org/10.1016/j.trpro. 2019.07.169

Wang, Z., Leng, L. L., Wang, S., Li, G. F., \& Zhao, Y. W. (2020). A hyperheuristic approach for locationrouting problem of cold chain logistics considering fuel consumption. Computational Intelligence and Neuroscience. https://doi.org/10.1155/2020/8395754

Wiktorowska-Jasik, A. (2017). Land transport services—service structure and development dynamics analysis. Ekonomiczne Problemy Ustug, 39128, 93-105. https://doi.org/10.18276/epu.2017.128-07

Wu, X., Zhang, L., \& Luo, M. (2020). Current strategic planning for sustainability in international shipping. Environment, Development and Sustainability, 22, 1729-1747. https://doi.org/10.1007/ s10668-018-00303-2 
Yun, G., Yalcin, M. G., Hales, D. N., \& Kwon, H. Y. (2019). Interactions in sustainable supply chain management: A framework review. International Journal of Logistics Management, 30(1), 140-173. https://doi.org/10.1108/JLLM-05-2017-0112

Publisher's Note Springer Nature remains neutral with regard to jurisdictional claims in published maps and institutional affiliations. 